\title{
Dismantling worker categories: the primary duty of care, and worker consultation, participation and representation, in the model Work Health and Safety Bill 2009
}

\author{
Richard Johnstone B Bus Sci LLB (Hons) PhD, Griffith University, Australia
}

\begin{abstract}
Late in 2009, the Australian Workplace Relations Ministers' Council endorsed the model Work Health and Safety Bill 2009, which is to be adopted by all Australian governments (federal, state and territory) from 01 January 2012. This paper describes and analyses two key sets of provisions in this model legislation. The first establishes a 'primary' duty of care imposed not on 'employers' but on persons conducting a business or undertaking, and owed to all kinds of workers engaged, directed or influenced by the person conducting the business or undertaking. The second encompasses broad duties on all persons conducting a business or undertaking to consult with workers who carry out work for the business or undertaking and who are directly affected by a work health and safety issue, and to facilitate the election of health and safety representatives representing all workers who carry out work for the business or undertaking. These provisions arguably make a significant contribution to solving a problem faced by occupational safety and health regulators around the world - modifying regulation to accommodate all forms of precarious work.
\end{abstract}

\section{Key words}

General duties, occupational safety and health regulation, precarious work, worker consultation and participation

\section{Introduction}

In keeping with similar trends over the world, in Australia the world of work has changed markedly since the 1980s, particularly in the increased incidence of downsizing and outsourcing within firms, resulting in greater use of more flexible or less secure forms of work, such as on-call, temporary and fixed-term employment (including labour hire arrangements); the conversion of employees into independent contractors; business format franchise arrangements; and temporary movements of workers, such as guest workers. As has been the case with most labour regulation around the world, ${ }^{1-4}$ the post-Robens Australian occupational safety and health $(\mathrm{OSH})$ statutes (which, for constitutional reasons, are principally enactments of the six state and two territory governments)* were originally built on the paradigm of the employment relationship and assumed that typical work arrangements

\footnotetext{
* The Commonwealth government's jurisdiction is confined to regulating OSH for its own employees and employees of employers licensed to self-insure under the Safety, Rehabilitation and Compensation Act 1988 (Commonwealth, Cth). Until the end of 2011, the general statutes were: the Occupational Health and Safety Act 1991 (Cth) (federal public sector employment and self-insurers under the Commonwealth workers' compensation legislation); the Occupational Health and Safety Act 2000 (New South Wales, NSW); the Occupational Health and Safety Act 2004 (Victoria, Vic); the Workplace Health and Safety Act 1995 (Queensland, Qld); the
} 
involved a single employer employing employees on contracts of employment, and with work activities confined to the employer's workplace. ${ }^{1,5}$

The increased incidence of outsourcing and precarious work has posed major challenges to labour regulation in general, and this model of OSH regulation in particular. Lippel notes that while there have been detailed studies of the health effects of precarious work, 'little work has been done in developing the analytical tools necessary to evaluate regulatory failure from a purely legal perspective'. ${ }^{6}$ Lippel's own analysis of the health and safety legislation in Quebec $^{7}$ shows that 'in Quebec, as elsewhere, workers in precarious employment are often the most at risk and the least well protected'. Other studies make a similar point. ${ }^{8-10}$

There have been some regulatory developments aimed at extending legal health and safety duties to parties other than employers. In Norway in the 1980s, and then in Sweden in the early 1990s, 'internal control' legislation was introduced, in part in response to issues arising from elaborate subcontracting networks in the offshore oil industry. The 1992 European Union Directive on the implementation of minimum health and safety requirements at temporary or mobile construction sites was also an attempt to impose legal health and safety obligations on principal contractors and others in contracting chains on construction sites. Further, there are international and national examples of voluntary codes to improve OSH in supply chains, and mandatory supply chain regulation has been introduced in Australia in the road transport industry (with specific OSH regulations governing fatigue in New South Wales), as well as in the clothing industry in New South Wales, Queensland and South Australia. ${ }^{11-14}$ Most of these initiatives have focused on specific industries and/or specific types of contractual arrangement. More generally, in the UK and Australia, as this paper will show, some of these challenges were at least partially met by the breadth of the general duty provisions in the UK's Health and Safety at Work Act 1974 and the pre-model Act Australian OSH statutes. In relation to worker representation and participation, a key initiative has been the Swedish system of regional safety representatives, which has been adopted in a few other European countries. ${ }^{15}$ But the most comprehensive approach to addressing the health and safety risks faced by all types of precarious worker, and enabling all kinds of worker to participate in workplace arrangements for OSH, is to be found in the recently drafted harmonised Australian model Work Health and Safety Bill 2009. ${ }^{16}$

The harmonised legislation is the result of the National Review into Model Occupational Health and Safety Laws, commissioned by the Australian federal government in 2008 as part of the federal government's initiative to harmonise Australian OSH statutory provisions. ${ }^{\dagger}$ The National Review was required, as part of its brief, to take into account the changing nature of work organisation and work relationships in proposing a model OSH statute to be adopted by each of the governments in the Australian federal system. In December 2009, the

Occupational Health, Safety and Welfare Act 1986 (South Australia); the Occupational Safety and Health Act 1984 (Western Australia, WA); the Workplace Health and Safety Act 1995 (Tasmania); the Work Safety Act 2008 (Australian Capital Territory, ACT); and the Workplace Health and Safety Act 2007 (Northern Territory, NT). In this paper, these statutes will be called 'the pre-model Act OSH statutes'.

${ }^{\dagger}$ Despite being strongly influenced by the UK Robens model, closer scrutiny of the different Australian OSH statutes that were enacted from the late 1970s revealed significant differences in form, detail and substantive matters: see the analyses of the Australian OSH regulatory provisions in Johnstone, ${ }^{17}$ especially chapters 3 to 8 . For a fuller description of the history of attempts at national uniformity, see Johnstone. ${ }^{18}$ 
Australian Workplace Relations Ministers' Council (WRMC) approved the model Work Health and Safety Bill 2009 ('the model Act'). At the time of writing, the model Act is being adopted by all Australian governments to replace their existing OSH statutes by the beginning of 2012 .

A key feature of the model Act is that its provisions break down the boundaries that mainstream labour law has been careful to build between different categories of workers and, in particular, the boundaries between 'employees' directly 'employed' by an 'employer' and other kinds of worker. The model Act does this principally by rejecting the existing regulatory approach of making 'employers' and 'employees' the key agents in the regulatory model, and by replacing, respectively, 'employer' with 'a person conducting a business or undertaking' (PCBU) and 'employee' with 'worker', very broadly defined to include all people carrying out 'work in any capacity' for a PCBU. At the heart of the model Act is the primary duty of care, imposed on a PCBU and owed to 'workers' engaged by, caused to be engaged by, or carrying out work directed or influenced by, the PCBU and to 'others'. Another notable feature of the model Act is that it requires the PCBU to consult all 'workers' who carry out work for the business or undertaking who are, or are likely to be, directly affected by a matter relating to work health and safety. Further, all 'workers' who carry out work for the PCBU can be involved in processes to establish 'work groups' and to elect health and safety representatives.

This paper first explains how the pre-model Act Australian OSH statutes (and the UK's Health and Safety at Work Act 1974) only partially addressed the challenges posed by the increased use of forms of work relationship that fell outside the employment paradigm. It then analyses the key provisions in the model OSH Act and shows how they broaden the scope of Australian OSH regulation to protect all kinds of worker. Because of the special focus of this journal issue on labour hire and casual employment arrangements, the application of the new statutory arrangements to these work relationships will be emphasised.

\section{The pre-model Act OSH statutes and workers who were not employees}

\section{General duties}

The pre-model Act Australian OSH statutes each contained an employer's general duty to employees that largely resembled the duty in section 2 of the UK Health and Safety at Work Act 1974. For example, section 21 of the Victorian Occupational Health and Safety Act 2004 stipulated that an employer must, so far as is reasonably practicable, provide and maintain for employees of the employer a working environment that was safe and without risks to health. Clearly this duty applies to 'employees' of the employer, whether they are permanent, part-time or temporary (casual) employees.

The courts took a broad approach to interpreting these duties, so that the duties were able to adapt to some extent to work relationships outside the typical employment relationship. For example, from the late 1990s the Australian courts, particularly the New South Wales Industrial Relations Commission, interpreted the duty to impose significant obligations on a labour hire agency (the employer) in relation to its labour hire employees placed with client firms. A good example was the decision in Drake Personnel Limited $v$ WorkCover Authority of New South Wales (Inspector Ch'ng) (1999) 90 IR 432. Prior to placement, Drake had shown the employee a training video, provided her with an instructional booklet, and had sent a field staff consultant to the client's premises to inspect the then properly guarded 
machine that the employee was said by the client to be working on, and went through the procedure she was to perform. The worker was subsequently asked by the client to work on another machine, which was unguarded, and she suffered an injury. The client had not told Drake that the employee would be required to work on that machine, and the field staff consultant had not been shown the machine when she visited the premises. The Commission accepted that a risk that Drake had to guard against was the risk that its employee would be instructed to work on an unguarded machine, and Drake's omission was a failure to require the client to notify Drake before transferring the employee to work on another machine. The Commission (at 455-456) stated that:

... an employer who sends its employees into another workplace over which they exercise limited control is, for that reason, under a particular positive obligation to ensure that those premises, or the work done, do not present a threat to the health, safety or welfare of those employees... A labour hire company cannot escape liability merely because the client to whom an employee is hired out is also under a duty to ensure that persons working at their workplace are not exposed to risks to their health and safety or because of some alleged implied obligation to inform the labour hire company of the work to be performed... This obligation would, in appropriate circumstances, require it to ensure that its employees are not instructed to, and do not, carry out work in a manner that is unsafe. In the present case, it seems to us that this would require, at the very least, that the appellant give an express instruction to the client and its employee that it be notified before the employee is instructed to work on a different machine.

A second example of the broad approach taken by the courts was that almost from the outset the courts accepted that, in providing a healthy and safe working environment for employees, the employer had to ensure that all workers, including contractors, sub-contractors and labour hire workers, were - as far as is reasonably practicable - instructed, trained and supervised so that their work practices did not threaten the health and safety of the employer's employees. * Thus, a host employer had to ensure, so far as was reasonably practicable, that workers hired through a labour hire company were adequately trained, instructed and supervised so that they did not put the employer's employees at risk.

A third example can be found in section 19(1) of the South Australian Occupational Health, Safety and Welfare Act 1986, which expressed the employer's duty to employees to apply 'in respect of each employee employed or engaged by the employer'. The expression 'engaged' was interpreted very broadly so that a person employed under a contract of employment by a third party (in this case an 'employee' employed by a labour hire agency), and who worked for 'the employer' pursuant to an agreement between the employer and labour hire agency, was owed a duty because the 'employer' had 'engaged' the labour hire 'employee', despite there being no contract between the 'employer' and the 'employee'. (See also the definition of 'employee' in section 4 of the Act.)

Some of the Australian OSH statutes themselves expanded the meaning of 'employee' by

\footnotetext{
* See, for example, $R v$ Swan Hunter Shipbuilders [1982] 1 All ER 264; see also WorkCover Authority of NSW $v$ Crown in the Right of the State of NSW (Police Service of New South Wales) (No 2) (2001) 104 IR 268 at para 24.

${ }^{\dagger}$ Moore $v$ Fielders Steel Roofing Pty Ltd [2003] SAIRC 75.
} 
deeming contractors and their employees to be 'employees' protected by the employer's general duty to employees. ${ }^{19 *}$ These deeming provisions, particularly the term 'engaged', have generally been broadly interpreted by the courts ${ }^{\dagger}$ so that subcontractors and subsubcontractors and their employees were deemed to be 'employees' of the employer.

Another statutory approach was simply to widen the scope of the duty to protect 'workers', broadly defined, rather than 'employees'. For example, the general duty in the Queensland Workplace Health and Safety Act 1995 was owed to 'workers', defined as persons who do 'work, other than under a contract for services, for or at the direction of an employer', and included volunteers. ${ }^{\ddagger}$ As a result, a host employer would owe a duty of care to a labour hire worker if the worker was directed by the employer, even if there was no contract between them.

Finally, the most significant statutory provisions were the general duties on employers and self-employed persons in relation to persons other than employees. As was the case in the UK, these provisions were introduced to protect 'the public' from workplace hazards,$^{20}$ but clearly also applied to workers other than employees. Initially, the most far-reaching provision was in the Victorian OSH statutes ${ }^{\S}$ (which largely reproduced the provisions in section 3 of the UK's Health and Safety at Work Act 1974) which, in essence, provided that employers and self-employed persons must ensure that persons who are not employees were 'not exposed' to OSH risks arising from 'the conduct of the undertaking'." The Queensland provision in section 28 of the Workplace Health and Safety Act 1995 was very similar, although the duty was owed to 'workers' (see above) and from 2005 the duty was owed by a person conducting a business or undertaking. ${ }^{21}$ The courts took a broad approach to interpreting the key expressions 'exposed to risk' ' and 'conduct of the

\footnotetext{
* For example, section 21(3) of the 1985 and 2004 Victorian Occupational Health and Safety Acts. The Western Australian Occupational Safety and Health Act 1984, in sections 23D to 23F, went further to 'deem' all labour hire workers to be 'employees' of the labour hire agency and host respectively, and 'labour arrangements in general' to be under an employment contract, for the purposes of the employer's general duty in relation to matters over which the agency, host or person has the capacity to exercise control over the work.
}

† See, particularly, The Queen v ACR Roofing Pty Ltd (2004) 11 VR 187.

${ }^{\ddagger}$ A similar approach was taken in the Work Safety Act 2008 (ACT), and the Workplace Health and Safety Act 2007 (NT) - see further below.

$\checkmark$ See section 22 of the Occupational Health and Safety Act 1985 (Vic), reproduced in sections 23 and 24 of the Occupational Health and Safety Act 2004.

"Sections 8(2) and 9(1) of the Occupational Health and Safety Act 2000 (NSW) were similar to the Victorian and Queensland provisions, but specified that the duty only applied to non-employees while they were at the employer's or self-employed person's 'place of work'. They would not protect workers who were not employees engaged in work away from the employer's workplace - such as owner-drivers and outworkers who were independent contractors. The other OSH statutes did not build the duty to others around concepts of exposure to risk from the conduct of the undertaking, and are more limited in their application to workers who are not employees. 
undertaking'. $22,23 *$ The importance of these provisions was that they imposed a hierarchy of overlapping and complementary responsibilities on the different levels of employers and selfemployed persons (including contractors and sub-contractors) in relation to all parties below them in the contractual chain or affected by the conduct of their undertaking. ${ }^{23} \mathrm{~A}$ host employer would clearly owe a duty of care under these provisions to a labour hire worker, regardless of whether the worker was an employee or an independent contractor.

What these examples show is that the courts have been prepared to interpret the general duties broadly to cover, where possible, work relationships other than the employment relationship. The last two examples provide the seeds of the new approach taken up in the model OSH Act, which is described and analysed in the following section.

\section{Workplace participation}

Workplace participation was also tightly constrained under the pre-model Act Australian OSH statutes, most of which limited participation as health and safety representatives and in health and safety committees to 'employees' based 'at the workplace' in relation to their 'employer'. ${ }^{24}$ This clearly limited consultation, representation, participation and protection to the traditional employment paradigm: employees and single employers at the employer's workplace. It should be noted that some of the OSH statutes did seek to include other kinds of worker in the participation provisions: for example, the Workplace Health and Safety Act 1995 (Qld) vested participation rights on 'workers', defined above, rather than 'employees', an approach later adopted by the Workplace Health and Safety Act 2007 (NT) and the Work Safety Act 2008 (ACT); the Victorian Occupational Health and Safety Act 2004 and the Western Australian Occupational Safety and Health Act 1986 had complex provisions enabling participatory processes to cover more than one employer and more than one workplace; and the Victorian Act enabled health and safety representatives to represent independent contractors. ${ }^{24 \dagger}$ Again, the Queensland (and ACT and NT) approach points the way to the types of provision introduced in the model OSH Act, which are described and analysed later in this paper.

\section{Breaking down the boundaries: the primary duty of care in the model OSH Act}

\section{The approach recommended by the National Review}

The National OHS Review Panel's recommendations in its First report to the Workplace Relations Ministers' Council ${ }^{25}$ were strongly motivated by the need to ensure that the general duty in the model OSH Act would cover all kinds of work relationship and address the wide range of known and emerging hazards. ${ }^{26}$ The First report stressed that the duty should not be

* Whittaker v Delmina Pty Ltd (1998) 87 IR 268 at 280-281; Victorian WorkCover Authority v Horsham Rural City Council [2008] VSC 404; WorkCover Authority of New South Wales (Inspector Martin) $v$ Edmund Hubert Kuipers and Civil Services Pty Ltd [2004] NSWIRComm 303 para [55]; Inspector Alwyn Piggott v CSR Emoleum Services Pty Ltd [2003] NSWIRComm 282; R v Associated Octel Co Ltd [1996] 4 All ER 846 at 851-852; $R v$ Mara [1987] 1 WLR 87; and Sterling-Winthrop Group Limited $v$ Allen (1987) SCCR 25. These cases establish that the expression 'conduct of the undertaking' includes ancillary matters such as cleaning, repairing and maintaining plant, obtaining supplies and making deliveries. Whittaker $v$ Delmina Pty $L t d$ establishes clearly that the conduct of an undertaking is not confined to the workplace of the person conducting the undertaking.

† See Occupational Health and Safety Act 2004 (Vic) section 44(1)(e) and Part 7, Division 2, and Occupational Safety and Health Act 1986 (WA) s 30B. 
'limited to any particular relationships', especially not to the employment relationship. It considered that the approach of imposing the principal general duty on an 'employer' and a 'self-employed person' was 'too limited, as it maintains the link to the employment relationship as a determinant of the duty of care' and that 'the changing nature of work arrangements and relationships make this link no longer sufficient to protect all persons engaged in work activities'. ${ }^{27}$ For example, a person with active control or influence over the way work is conducted might be neither an employer nor a self-employed person, ${ }^{27}$ while the person carrying out the work might do so under the effective direction or influence of someone who has not engaged that person under a contract of employment, ${ }^{28}$ as would be the case with labour hire workers. The First report ${ }^{25}$ recommended that the primary duty of care should not be limited to the workplace, but 'should apply to any work activity and work consequences, wherever they may occur, resulting from the conduct of the business or undertaking' (recommendation 17).*

The First report ${ }^{25}$ further recommended (recommendations 10 to 21) that there be a 'primary duty of care', owed by a 'person conducting a business or an undertaking' and owed to 'workers' and 'others'. It recommended that the primary duty be to ensure workers and others 'are not exposed to a risk to their health and safety arising from the conduct of the undertaking'. While the proposed primary duty clearly drew on the general duty in section 28 of the Workplace Health and Safety Act 1995 which, as noted above, since 2005 has been owed by a PCBU to 'workers', the primary duty proposal was innovative in that it sought to impose an overarching umbrella duty, not just a broadly phrased general duty on employers.

An interesting aspect of these developments is that they are largely based on a conceptual development of the general duty provisions, rather than on any rigorous evaluation of the implementation and effectiveness of the pre-model Act general duties in relation to precarious workers. Nevertheless, they appear, at least at a conceptual level, to provide a solution to the problem of ensuring the health and safety of all kinds of precarious worker.

The primary duty in the model Act

These recommendations have been implemented in the model Act, in section 19, although the wording of the duty has been altered. Whereas the First report proposed a primary duty contained in a single clause, the duties to 'workers' and 'others' in the model Act are to be found in separate sub-sections.

The duty to 'workers' is established in section 19(1):

A person conducting a business or undertaking must ensure, so far as is reasonably practicable, the health and safety of:

(a) workers engaged, or caused to be engaged by the person; and

(b) workers whose activities in carrying out work are influenced or directed by the person, while the workers are at work in the business or undertaking.

The duty to 'others' is in section 19(2):

A person conducting a business or undertaking must ensure, so far as is reasonably

\footnotetext{
* For a good example, see Whittaker v Delmina Pty Ltd (1998) 87 IR 268.
} 
practicable, that the health and safety of other persons is not put at risk from work carried out as part of the conduct of the business or undertaking.

The duty to workers in section 19(1) imposes a higher standard of care (to 'ensure' the health and safety of the protected workers) than the duty to others in section 19(2) (not to 'put at risk' the health and safety of others), largely out of concern that the 'public safety' dimensions of the primary duty would be too extensive and onerous on PCBUs.

It is clear that the relationship between the PCBU and the protected workers in section 19(1) does not have to be a direct contractual relationship, so that at a minimum the worker must have been 'caused to be engaged' by the PCBU (for example, where a worker is placed with a PCBU by an employment agency that technically employs or engages the worker ${ }^{29}$ or the worker's work activities must be 'influenced or directed' by the PCBU. ${ }^{30}$ The Australian courts will most likely interpret 'engaged' very broadly to include not only contractors engaged by the person, but also sub-contractors, sub-subcontractors, and so on. ${ }^{*}$ Clearly both a labour hire agency and a host employer will owe the primary duty to the labour hire worker, and the agency's duty will extend beyond the agency's own workplace because there is no suggestion that the duty is confined to work carried out at the PCBU's workplace. ${ }^{31 \dagger}$

Section 19(3) of the model Work Health and Safety Bill fleshes out some of the content of the primary duty and provides that:

... without limiting subsections (1) and (2), a person conducting a business or undertaking must ensure, so far as is reasonably practicable:

(a) the provision and maintenance of a work environment without risks to health and safety; and

(b) the provision and maintenance of safe plant and structures; and

(c) the provision and maintenance of safe systems of work; and

(d) the safe use, handling, storage and transport of plant, structures and substances; and

(e) the provision of adequate facilities for the welfare at work of workers in carrying out work for the business or undertaking, including ensuring access to those facilities; and

(f) the provision of any information, training, instruction or supervision that is necessary to protect all persons from risks to their health and safety arising from work carried out as part of the conduct of the business or undertaking; and

(g) that the health of workers and the conditions at the workplace are monitored for the purpose of preventing illness or injury of workers arising from the conduct of the business or undertaking.

The duty is preventive and it is most likely that the Australian courts will hold that it requires the PCBU to take a structured, systematic approach to OSH, rather than endeavour to comply with these obligations on an ad hoc basis, looking at particular matters from time to time. ${ }^{32}$ It is an ongoing duty, so that if measures are not systematic and are not maintained and reviewed over time to ensure that the measures are institutionalised, the PCBU will be in

\footnotetext{
* See The Queen v ACR Roofing Pty Ltd (2004) 11 VR 187 and Moore v Fielders Steel Roofing Pty Ltd [2003] SAIRC 75, as discussed above.

† The Explanatory memorandum, paragraph 79, makes it clear that the primary duty 'is tied to work activities wherever they occur and is not limited to the confines of the physical workplace'.
} 
breach of its primary duty of care. The duty is also inchoate, in that it will be contravened if the health and safety of workers is not ensured, as far as is reasonably practicable, because workers are exposed to risks, even if workers do not suffer any form of illness or injury.*

\section{Who is a 'person conducting a business or undertaking' and a 'worker'?}

Section 5 of the model Act states that a person conducts a business or undertaking whether doing so alone or with others, and whether or not for profit or gain. The definition of a PCBU includes a business or undertaking conducted as a partnership (in which case each partner is a PCBU) or as an unincorporated association. Excluded from the definition of a PCBU are persons engaged solely as a worker or officer of the business or undertaking, an elected member of a local authority acting in that capacity, and volunteer associations (a group of volunteers working together for one or more community purposes where none of the volunteers engages any person to carry out work for the volunteer organisation). The model Act is careful to make it clear in section 19(5) that a 'self-employed person' is a PCBU. Thus, it is clear that a PCBU can be a corporation, a sole proprietor, a selfemployed person, a partnership or an unincorporated association, and can be a principal contractor, head contractor, franchiser or the Crown. ${ }^{33}$

It is not clear from the model Act what the precise scope of the conduct of the business or undertaking is. The extent of the undertaking is a question of fact, ${ }^{\dagger}$ and might require careful analysis of complex business structures. ${ }^{\ddagger}$ An undertaking is still being conducted even after the actual work is completed; for example, after a building is demolished, the undertaking continues until all works have been completed. ${ }^{\$}$ More than one person may be conducting an undertaking in any one situation."

'Workers' are defined very broadly in section 7 to be persons carrying out 'work in any capacity' for a PCBU:

\footnotetext{
* See R v Australian Char Pty Ltd (1995) 5 VIR 600 at 612; Haynes v C I \& D Manufacturing Pty Ltd (1995) 60 IR 149 at 157-159; Boral Gas (NSW) v Magill (1995) 58 IR 363 at 367 (per Fisher P) and 388 (per Hill J); WorkCover Authority of New South Wales (Inspector Carmody) v Byrne Civil Engineering Constructions Pty Ltd (No 1) (2001) 103 IR 80 at 110-111; WorkCover Authority of New South Wales (Inspector Byer) v Cleary Bros (Bombo) Pty Ltd (2001) 110 IR 182 at 201.

${ }^{\dagger}$ Inspector Alwyn Piggott $v$ CSR Emoleum Services Pty Ltd [2003] NSWIRComm 282 at para [226]; R $v$ Associated Octel Co Ltd [1996] 4 All ER 846.

‡ See Inspector Alwyn Piggott v CSR Emoleum Services Pty Ltd [2003] NSWIRComm 282; WorkCover Authority of New South Wales (Inspector Yeung) v Thiess Pty Ltd [2003] NSWIRComm 325; and WorkCover Authority of New South Wales (Inspector Reid) $v$ CSR Limited t/a CSR Wood Panels (2001) 109 IR 275 at 286-289.
}

${ }^{\S}$ Inspector Maltby $v$ Harris Excavations and Demolition Pty Ltd (unreported, Industrial Relations Commission of New South Wales, Cahill VP, 2 May 1997); WorkCover Authority (NSW) v Morrison [2001] NSWIRComm 325.

"WorkCover Authority of New South Wales $v$ Techniskill-Namutoni Pty Ltd [1995] NSWIRComm 127 at [para 8]; R v Mara [1987] 1 WLR 87. 
... including work:

(a) as an employee; or

(b) as a contractor or sub-contractor; or

(c) as an employee of a contractor or sub-contractor; or

(d) as an employee of a labour hire company who has been assigned work in the person's business or undertaking; or

(e) as an outworker; or

(f) as an apprentice or trainee; or

(g) as a student gaining work experience; or

(h) as a volunteer.*

These are examples of the kinds of person falling within the definition of 'worker', and are 'illustrative only and are not intended to be exhaustive'. ${ }^{34}$ Section $7(3)$ makes it clear that a self-employed person may be both a PCBU and a worker.

\section{Reasonably practicable}

The general duties in the model Act are qualified by the expression 'reasonably practicable', which is defined in section 18 as:

... that which is, or was at a particular time, reasonably able to be done in relation to ensuring health and safety, taking into account and weighing up all relevant matters including:

(a) the likelihood of the hazard or the risk concerned occurring; and

(b) the degree of harm that might result from the hazard or the risk; and

(c) what the person concerned knows, or ought reasonably to know, about:

(i) the hazard or the risk; and

(ii) ways of eliminating or minimising the risk; and

(d) the availability and suitability of ways to eliminate or minimise the risk; and

(e) after assessing the extent of the risk and the available ways of eliminating or minimising the risk, the cost associated with available ways of eliminating or minimising the risk, including whether the cost is grossly disproportionate to the risk.

There are three notable features of this definition. First, consistent with previous formulations, ${ }^{\dagger}$ it sets out an objective test: that is, what would a reasonable duty holder do in the circumstances? Second, again consistent with previous formulations, 'all relevant matters', including the listed matters, have to be 'weighed up'. Finally, and crucially, the issue of 'the cost associated with available ways of eliminating or minimising the risk' is to be quarantined in the weighing up in the sense that it is only to be considered 'after' the other factors are 'weighed up', and is then only significant to the extent that 'the cost is grossly disproportionate to the risk'.

In a prosecution for an offence against the primary duty, the prosecutor bears the onus of proving that reasonably practicable measures were not taken to address a risk. This was the

\footnotetext{
* Section 4 of the model Act defines a 'volunteer' as 'a person who is acting on a voluntary basis (irrespective of whether the person receives out-of-pocket expenses)'.

† See, for example, Edwards v National Coal Board [1949] 1 KB 704 at 712; [1949] 1 All ER 743; Slivak v Lurgi (Australia) Pty Ltd (2001) 205 CLR 304 at 322-323; Holmes v Spence (1992) 5 VIR 119; and WorkCover Authority of New South Wales (Inspector Patton) v Fletcher Constructions Australia Ltd (2002) 123 IR.
} 
recommendation (recommendation 62; see also recommendation 50) of the First report, ${ }^{35}$ and the drafting of the primary duty to include 'reasonably practicable' as part of the duty of care clearly indicates that the onus of proving all elements of a general duty offence, including the reasonable practicability of measures to eliminate or minimise the risk, lies with the prosecutor.* $^{*}$

The duty of workers

Section 28 of the model Act also places a duty on a worker (apart from a worker who is a 'selfemployed person’ ${ }^{\dagger}$, while at work, to:

(a) take reasonable care for his or her own health and safety; and

(b) take reasonable care that his or her acts or omissions do not adversely affect the health and safety of other persons; and

(c) comply, so far as the worker is reasonably able, with any reasonable instruction that is given by the person conducting the business to allow the person to comply with this Act; and

(d) co-operate with any reasonable policy or procedure of the person conducting the business or undertaking relating to health or safety at the workplace that has been notified to workers.

Multiple duty holders and the duty to consult, co-operate and co-ordinate Finally, the model Act, in sections 14 to 16 , sets out a series of principles governing the operation of the general duty provisions, including the primary duty. A person can have more than one duty by virtue of being in more than one class of duty holder. Where there are multiple duty holders (for example, the 'host' employer and the labour hire agency), a duty cannot be transferred to another person. More than one person can concurrently have the same duty and in those instances each person must fully discharge the duty. If more than one person has a duty for the same matter, each person retains responsibility for the person's duty in relation to the matter, and must discharge the person's duty to the extent to which the person has the capacity to influence and control the matter or would have had that capacity but for an agreement or arrangement purporting to limit or remove that capacity. Most importantly, section 46 provides that if more than one person has a duty in respect of the same matter under the model Act, each person with the duty must, so far as is reasonably practicable, consult, cooperate and co-ordinate activities with all other persons who have a duty in relation to the same matter. The maximum penalty for non-compliance with this section is, in the case of an individual, $\mathrm{A} \$ 20,000$, and in the case of a body corporate, $\mathrm{A} \$ 100,000$. This is an extremely important provision in work situations where more than one PCBU can affect the health and safety of workers engaged to carry out work. All PCBUs must consult each other, co-operate and co-ordinate their work activities and OSH measures. For example, the labour hire agency and the host employer must consult each other and co-ordinate their OSH risk management systems.

Broader 'worker' participation: consultation and representation Earlier in this paper it was noted that the pre-model Act Australian OSH statutes tended to

\footnotetext{
* Chugg v Pacific Dunlop (1990) 170 CLR 249; see also Laing O’Rourke (BMC) Pty Ltd v Kirwin [2011] WASCA 117 para [71].
}

' See the definition of 'worker' above; also, see Workplace Relations Ministers' Council. ${ }^{36}$ 
confine processes for employee participation in OSH to 'employees' in relation to their 'employer' at the employer's workplace. One of the least noticed highly significant changes in Australian OSH regulation is that although the model Act largely adopts the Victorian model of consultation, representation and participation, it does not use the concepts of 'employer' and 'employee', but rather continues to use the terms 'person conducting a business or undertaking' and 'worker', as defined above.

Consequently, the key provisions in Part 5, Division 2: 'Consultation with workers' (sections 47 and 48) provide that a PCBU 'must, so far as is reasonably practicable," consult... with workers who carry out work for the business or undertaking who are, or are likely to be, directly affected by a matter relating to work health and safety'. If the PCBU and the workers have agreed to procedures for consultation, the consultation must be in accordance with those procedures; and if workers are represented by a health and safety representative, consultation must involve the representative. Consultation requires:

- sharing relevant information with workers

- giving workers a reasonable opportunity to express their views and raise work health and safety issues, and to contribute to the decision-making process

- the PCBU to take into account workers' views

- consulted workers to be advised of the outcomes of the consultations in a timely manner.

Section 49 specifies that the work health and safety matters where consultation is required include:

- identifying hazards and assessing risks to health and safety arising from the work to be carried out by the business or undertaking and making decisions about ways to eliminate or minimise those risks

- making decisions about the adequacy of facilities for the welfare of workers

- proposing changes that may affect the health or safety of workers

- making decisions about the procedures for consulting with workers, resolving work health or safety issues at the workplace, and monitoring the health of workers or the conditions at any workplace under the management or control of the PCBU

- providing information and training for workers.

Consequently, it is clear that the model Act requires all PCBUs to consult all workers (as defined in section 7) who carry out work for the business or undertaking and who are likely to be directly affected by a matter relating to work health and safety. Clearly, there will be situations where, because of the transient nature of the work, it will be difficult for the PCBU to consult a worker. For example, some labour hire workers might only be at a workplace for a few days. Nevertheless, the duty on the PCBU is to consult to the extent that consultation can be suitably accomplished in the circumstances, and it is difficult to see why in most circumstances a host PCBU will not be able to consult labour hire workers in the same way as permanent employees are consulted - at least while the labour hire worker is at the workplace.

Similarly, the provisions for the negotiation of 'work groups' in which health and safety

\footnotetext{
* 'Reasonably practicable' here is not as defined in section 18 , but rather is to be given its usual meaning, which in this situation would be to consult to the extent that consultation can be suitably accomplished in the circumstances.
} 
representatives can be elected (in Part 5, Division 3) are built around PCBUs and 'workers', rather than employers and employees, and can include multiple PCBUs and multiple workplaces. Thus, a worker who carries out work for a business or undertaking can request the PCBU to facilitate the election of one or more health and safety representatives (HSRs) to represent workers who carry out work for the business or undertaking. Workers and PCBUs are to negotiate to determine one or more 'work groups' at one or more workplaces, and a trade union may represent workers in these negotiations. The complex provisions in Subdivision 3 enable work groups to be determined for workers carrying out work for two or more PCBUs at one or more workplaces. The particulars of the work groups are to be determined by negotiation and agreement between each of the PCBUs and the workers.

Once work groups are negotiated, all workers in a work group can elect one HSR and a deputy HSR for each work group. If a majority of workers agree, the election may be conducted with the assistance of a trade union or other person or organisation. Elected HSRs have broad functions and powers, including representation, inspection and consultation, as well as information rights and the right to assistance. Trained HSRs also have powers enabling them to 'enforce' formal and substantive compliance with the model Act (see sections 72, 85(6) and 90(4)). These enforcement powers include the right (in Part 5, Division 7) to issue provisional improvement notices (essentially improvement notices issued by the HSR where the HSR reasonably believes there has been a contravention of the Act), and the right, as part of an issue resolution process (in Part 5, Divisions 5 and 6), to direct that work cease if the HSR has reasonable concern that to carry out the work would expose a worker to a serious risk to health and safety emanating from an immediate or imminent exposure to a hazard. Section 84 gives an individual worker the right to cease work if the worker has a similar concern. Section 87 enables the PCBU to direct workers who have ceased work to perform suitable alternative work.

These rights are profoundly important because they enable an HSR to take significant action, including stopping dangerous work, to protect every worker, regardless of their categorisation, at work in the HSR's work group. All workers, regardless of their categorisation, can protect themselves by refusing to perform dangerous work. For example, under section 84 of the model Act, labour hire workers have a right to refuse dangerous work that a host employer has directed them to perform, even though there is no contract between them.*

For completeness, it should be noted that Part 5, Division 4 provides that health and safety committees must be established for a business or undertaking by the PCBU within two months after being requested to do so by an HSR for a work group of workers carrying out work at that workplace, or by five or more workers at that workplace. The constitution of the health and safety committee may be agreed between the PCBU and the workers at the workplace, but at least half of the members of the committee must be workers who are not nominated by the PCBU. Thus, health and safety committees can include all types of worker, although the transient nature of a labour hire worker's presence at a particular business or undertaking may mean that, in practice, committees are made up of workers with a more permanent work relationship with the PCBU.

Of course, these consultations, participation and representation rights amount to little unless

\footnotetext{
* The common law right to refuse unreasonable or unlawful instructions of their employer obviously does not apply to workers who do not have a contract of employment with the person giving the directions.
} 
HSRs and workers can exercise them without fear of victimisation. The model Act (in Part 6) contains very strong anti-victimisation provisions, purporting to protect the exercise, or intended exercise, of rights, functions or powers, and the taking of action, by all persons (including workers, witnesses, HSRs, members of health and safety committees, and inspectors), by prohibiting discriminatory conduct (victimisation and coercion) for prohibited reasons in relation to the full range of OSH activities under the Act.

Finally, the model Act provides for union entry to provide limited protection for the health and safety of all workers, regardless of their categorisation. Part 7 of the model Act contains provisions for union officers or employees with work health and safety entry permits to investigate suspected contraventions of the model Act or to consult and advise 'relevant workers' (that is, workers who are members, or eligible to be members, of the union and who work at the workplace). If contraventions are found, the union entrant has no right to enforce, just the right to warn the PCBU.

\section{Implications for precarious workers}

This paper has analysed key provisions in the Australian model Work Health and Safety Bill 2009 that attempt to shift the Australian model of OSH regulation from a paradigm built on the traditional employment relationship - that is, an assumption that the kinds of worker to be protected are employees employed by a single employer - to a model that seeks to impose duties on all types of business organisation to ensure the health and safety, as far as reasonably practicable, of all people who carry out work for an organisation. In particular, the paper has examined two sets of provisions.

The first, the primary duty owed by PCBUs to workers, has effectively done away with the central assumption of the pre-model Act OSH regulatory model - that a duty of care should be owed only if the worker is employed under a contract of employment by an employer. Instead, it builds the regulatory model on a relationship between 'a person conducting a business or undertaking' (broadly defined to include most business enterprises or arrangements) and a 'worker' (very broadly defined to include all kinds of precarious worker, as well as employees). The relationship between the PCBU and worker need not be a direct contractual relationship, but rather one arising from the fact that the PCBU has, as part of the PCBU's business or undertaking, engaged (both directly or through a contractual chain), caused to engage, influenced or directed the worker. The PCBU must, as far as is reasonably practicable, ensure the health and safety of these workers. This is a very simple and elegant way of including all kinds of worker - including permanent full-time employees, part-time and causal employees, independent and dependent contractors, labour hire workers, outworkers and volunteers - within the protective scope of the primary duty.

This approach differs from the other initiatives (focusing on particular industries or contractual arrangements) discussed earlier in this paper, because it effectively removes all boundaries between 'employees' and other kinds of work relationship, and, at least on a formalistic level, treats all kinds of work relationship as being in the same broad category of 'worker'. It has far-reaching ramifications, because it means that, at least from an OSH perspective, there is no benefit to a PCBU in reconfiguring the PCBU's work arrangements to try to evade the PCBU's OSH obligations by, for example, converting 'employees' to 'contractors' and then re-engaging them, or in using agency workers rather than full-time employees. In each case, the PCBU's OSH obligations to the 'worker' would be the same: to ensure, as far as is reasonably practicable, the health and safety of the worker. This is an ongoing duty in the sense that it is owed to each worker for the entirety of the period that the 
PCBU conducts the business or undertaking and the worker is part of the business or undertaking.

The duty imposed on all primary duty holders to consult, co-operate and co-ordinate activities with all other duty holders (section 46) and the provisions reminding duty holders that duties are concurrent and non-delegable (sections 14 to 16) then mean that where work arrangements involve relationships between PCBUs, all PCBUs must fully discharge their primary duty, and each must consult and co-ordinate their activities with the other PCBUs. This is the case whether the relationships between PCBUs are relatively simple as would the case in a typical triangular labour hire arrangement, or more complex, as would be the case in vertical supply chains, or joint ventures with labour leasing arrangements. *

The second set of provisions, addressing worker consultation, representation and participation, and protecting workers from discriminatory and coercive conduct, take a similar approach. They are based on the provisions in the Victorian Occupational Health and Safety Act 2004, but instead of being built around the employment relationship - that is, situations where there is a contract of employment between 'employers' and 'employees' - they are couched in terms of 'a person conducting a business or undertaking' and 'workers' who 'carry out work for the business or undertaking'. This simple reform has far-reaching implications, in that in principle all workers, as defined in section 7 of the model Act, who carry out work for the business or undertaking and who are 'directly affected by a matter relating to work health and safety' must be consulted, where reasonably practicable, on work health and safety issues by the PCBU, and all workers who carry out work for the business or undertaking can participate in electing HSRs. Crucially, all types of worker now fall within the protective activities of the HSR elected for their work group (which includes the HSR's right to stop dangerous work), and have the individual right to refuse to perform dangerous work.

This does not mean, of course, that workers will necessarily benefit in practice from these legal changes. Regulators face the major challenge of developing suitable regulations, codes of practice and guidance material to provide guidance on exactly who is and is not a 'person conducting a business or undertaking', to flesh out the obligations in the primary duty and to provide guidance for PCBUs to enable compliance with the primary duty in the many situations to which the primary duty will need to be applied. The draft model regulations and codes of practice released in December 2010 did not provide such guidance. At the time of writing, the final regulations have not been publicly released.

The provisions for worker consultation, representation and participation are long and complex and, once again, regulators will need to provide good guidance to enable PCBUs to fulfil their duties, especially where a PCBU has a fleeting relationship with a worker, as will be the case when, for example, a PCBU engages or takes delivery from a courier, or where a temporary worker is engaged for a very short period of time.

OSH inspectorates also face major challenges to develop inspection approaches to include 'hard to reach' workplaces in their inspection strategies, and produce enforcement approaches tailored to complex work arrangements. Unions, too, will need to develop ways of organising workers and of exploiting the opportunity to recruit new members because of the expansion of the types of worker enabled to participate in OSH at work.

\footnotetext{
* See, for example, Inspector Alwyn Piggott v CSR Emoleum Services Pty Ltd [2003] NSWIRComm 282.
} 


\section{Conclusions}

The Australian model Work Health and Safety Bill 2009 has taken a very simple, yet subtle, approach to broadening its reach to include all kinds of worker performing work for persons conducting a business or undertaking. It is simple because, in essence, it has involved simply recasting the key players as 'persons conducting a business or undertaking' and as 'workers' (defined as any person carrying out 'work in any capacity' for a person conducting a business or undertaking), rather than as 'employers' and 'employees'. It is also subtle, because these major changes have been effected by otherwise largely adopting provisions already in place in some of the existing OSH statutes, particularly the Victorian Occupational Health and Safety Act and the Queensland Workplace Health and Safety Act, so that the expansion of the regulatory model to address all kinds of work relationship has been achieved with minimal dissent, largely because the attention of the peak employer and union bodies were focused on other controversial issues, such as whether the onus or proving 'reasonable practicability' in the general duties should lie with the prosecutor or defendant, and whether union secretaries should be able to initiate prosecutions.

The result is a primary duty that is a broad, flexible, all-encompassing 'umbrella duty' that builds on the 'duty to others' in the pre-model Act OSH statutes. The primary duty on the PCBU protects all categories of 'worker': contractors, sub-contractors, labour hire workers (whether employees or independent contractors), volunteers, outworkers and other home-based workers, and those working under other arrangements, including franchises, bailment (in the case, for example, of taxi drivers), share fishing and share farming. Similarly, the provisions in the model Act governing workforce consultation, representation and participation are all couched in terms of 'workers' and PCBUs, and, at least potentially, enable the full range of workers to participate in workplace arrangements for work health and safety.

Whether or not these provisions do in fact provide the comprehensive protection and opportunities for participation for all workers that they promise will, of course, depend on how they are implemented by the parties concerned, and enforced by the Australian work health and safety regulators.

\section{References}

1. Collins H. Ascription of legal responsibility to groups in complex patterns of economic integration. Modern Law Review 1990; 53 (6): 731-744.

2. Deakin S. Evolution of the employment relationship. In: Auer P and Grazier P (eds). The future of work, employment and social protection: dynamics of change and protection of workers. Geneva: International Institute for Labour Studies, 2002: 191-203.

3. Stone K V W. From widgets to digits: employment regulation for the changing workplace. Cambridge: Cambridge University Press, 2004.

4. Bernstein S, Lippel K, Tucker E and Vosko L. Precarious employment and law's flaws: identifying regulatory failure and securing effective protection for workers. In: Vosko L (ed). Precarious employment: understanding labour market insecurity in Canada. Montreal and Kingston: McGill-Queen's University Press, 2006.

5. Deakin S. The changing concept of the 'employer' in labour law. Industrial Law Journal 2001; 30 (1): 72-84.

6. Lippel K. Precarious employment and occupational health and safety regulation in Quebec. In: Vosko L (ed). Precarious employment: understanding labour market insecurity in Canada. Montreal and Kingston: McGill-Queen's University Press, 2006: 240.

7. Lippel K. Precarious employment and occupational health and safety regulation in 
Quebec. In: Vosko L (ed). Precarious employment: understanding labour market insecurity in Canada. Montreal and Kingston: McGill-Queen's University Press, 2006: 247.

8. Vosko L. Legitimating the triangular employment relationship: emerging international labour standards from a comparative perspective. Comparative Labor Law Journal 1997; 19 (1): 43-77.

9. Hasle P. Outsourcing and employer responsibility: a case study of occupational health and safety in the Danish public transport sector. Relations industrielles/Industrial Relations 2007; 62 (1): 96-117.

10. Johnstone R. Quinlan M and Mayhew C. Outsourcing risk? The regulation of OHS where contractors are employed. Comparative Labor Law and Policy Journal 2001; 22 (2\&3): 351-393.

11. James P, Johnstone R, Quinlan M and Walters D. Regulating supply chains to improve health and safety. Industrial law Journal 2007; 36 (2): 163-187.

12. Walters D and James P. Understanding the role of supply chains in influencing health and safety at work. IOSH Research Report. Wigston: IOSH, 2009. www.iosh.co.uk/ information_and_resources/research_and_development/research_fund/idoc.ashx?docid= c1116aa4-5a15-4049-aeac-89ee47147634\&version=-1. Viewed 18 November 2011.

13. Weil D and Mallo C. Regulating labour standards via supply chains: combining public/private interventions to improve workplace compliance. British Journal of Industrial Relations 2007; 45 (4): 791-814.

14. Weil D. Rethinking the regulation of vulnerable work in the USA: a sector based approach. Journal of Industrial Relations 2009; 51 (3): 411-430.

15. Frick K. Health and safety representation in small firms: a Swedish success under threat. In: Walters D and Nichols T (eds). Workplace health and safety - International perspectives on worker representation. Basingstoke: Palgrave Macmillan, 2009: 154-176.

16. www.safeworkaustralia.gov.au/AboutSafeWorkAustralia/WhatWeDo/Publications/ Documents/598/Model_Work_Health_and_Safety_Bill_23_June_2011.pdf. Viewed 29 November 2011.

17. Johnstone R. Occupational health and safety law and policy. 2nd edition. Pyrmont: Thompson Lawbook, 2004.

18. Johnstone R. Harmonising occupational health and safety regulation in Australia: the First report of the National OHS Review. Journal of Applied Law and Policy 2008; Issue 2008: 35-58

19. Johnstone R. Occupational health and safety law and policy. 2nd edition. Pyrmont: Thompson Lawbook, 2004: 187-189.

20. Robens, Lord. Safety and health at work: report of the Committee, 1970-1972. Cmnd 5034. London: HMSO, 1972: paragraphs 175-176 and chapter 10, especially page 290 and pages 294-297.

21. Johnstone R. From catch up to innovation: a history of occupational health and safety regulation in Queensland. In: Bowden B, Blackwood S, Rafferty C and Allan C (eds). Work \& strife in paradise: the history of labour relations in Queensland, 1859-2009. Sydney: Federation Press: 95-112.

22. Johnstone R. Paradigm crossed? The statutory occupational health and safety obligations of the business undertaking. Australian Journal of Labour Law 1999; 12 (2): 73-112.

23. Johnstone R. Regulating occupational health and safety in a changing labour market. In: Arup C, Gahan P, Howe J, Johnstone R, Mitchell R and O’Donnell A (eds). Labour law and labour market regulation. Sydney: Federation Press, 2006: 617-636.

24. Johnstone R, Quinlan M and Walters D. Statutory OHS workplace arrangements for the modern labour market. Journal of Industrial Relations 2005; 47 (1): 94-116. 
25. Commonwealth of Australia. First report to the Workplace Relations Ministers' Council (National OHS Review Panel). Canberra: Commonwealth of Australia, October 2008.

26. Commonwealth of Australia. First report to the Workplace Relations Ministers' Council (National OHS Review Panel). Canberra: Commonwealth of Australia, October 2008: 18 , xiii.

27. Commonwealth of Australia. First report to the Workplace Relations Ministers' Council (National OHS Review Panel). Canberra: Commonwealth of Australia, October 2008: 46.

28. Commonwealth of Australia. First report to the Workplace Relations Ministers' Council (National OHS Review Panel). Canberra: Commonwealth of Australia, October 2008: 47.

29. Safe Work Australia. Explanatory memorandum - Model Work Health and Safety Bill. Canberra: Safe Work Australia, 2 December 2010: paragraph 77.

30. Safe Work Australia. Explanatory memorandum - Model Work Health and Safety Bill. Canberra: Safe Work Australia, 2 December 2010: paragraph 74.

31. Safe Work Australia. Explanatory memorandum - Model Work Health and Safety Bill. Canberra: Safe Work Australia, 2 December 2010.

32. Bluff E and Johnstone R. The relationship between 'reasonably practicable' and risk management regulation. Australian Journal of Labour Law 2005; 18 (3): 197-233.

33. Safe Work Australia. Explanatory memorandum - Model Work Health and Safety Bill. Canberra: Safe Work Australia, 2 December 2010: paragraph 23.

34. Safe Work Australia. Explanatory memorandum - Model Work Health and Safety Bill. Canberra: Safe Work Australia, 2 December 2010: paragraph 99.

35. Safe Work Australia. Explanatory memorandum - Model Work Health and Safety Bill. Canberra: Safe Work Australia, 2 December 2010: paragraph 77.

36. Workplace Relations Ministers' Council. WRMC response to recommendations of the National Review into model OHS laws. 18 May 2009: 6. http://safeworkaustralia.gov.au/AboutSafeWorkAustralia/WhatWeDo/Publications/ Documents/515/WRMC81outcomesMay09.pdf. Viewed 29 November 2011. 